\title{
Formulation and evaluation of controlled-release matrix systems of ciprofloxacin
}

\author{
Venkata Ramana Malipeddi ${ }^{1, A-F}$, Rajendra Awasthi ${ }^{2, A-F}$, Kamal Dua ${ }^{3, A-F}$ \\ ${ }^{1}$ Amity Institute of Pharmacy, Amity University, Lucknow, India \\ ${ }^{2}$ NKBR College of Pharmacy \& Research Centre, Phaphunda, India \\ ${ }^{3}$ Discipline of Pharmacy, Graduate School of Health, University of Technology Sydney, Australia \\ A - research concept and design; $\mathrm{B}$ - collection and/or assembly of data; $\mathrm{C}$ - data analysis and interpretation; \\ $D$ - writing the article; $E$ - critical revision of the article; $F$ - final approval of the article
}

\section{Address for correspondence \\ Venkata Ramana Malipeddi}

E-mail: drmvramana@gmail.com

\section{Funding sources}

none declared

\section{Conflict of interest}

none declared

Received on August 27, 2017

Reviewed on December 18, 2017

Accepted on April 17, 2018

\begin{abstract}
Background. Ciprofloxacin is a broad-spectrum fluoroquinolone antibacterial drug to which most Gram-negative and many Gram-positive bacteria are highly susceptible. Fluoroquinolones are administered repeatedly, twice a day for 5 days, during the course of therapy. Hence, they require repeated administration. Ciprofloxacin qualifies as a drug candidate for a controlled-release drug delivery system.
\end{abstract}

Objectives. The present work was aimed to develop ciprofloxacin hydrochloride-containing matrix tablets by the wet granulation method.

Material and methods. The tablets were prepared using Ethoce $\mathrm{I}^{\mathrm{TM}} 100$ Premium and Eudragit ${ }^{\oplus} \mathrm{RS}$ PO (Evonik Laboratory, Mumbai, India) as a rate-controlling polymer. Granular dioctyl phthalate (DCP) was used as a diluent. An isopropyl alcohol and dichloromethane (1:1) mixture was used as a granulating agent. The effect of the formulation variables on tablet performance was examined based on weight variation, hardness, friability, thickness, and drug release profiles. The results suggested that the tablets had good integrity.

Results. The tablets were stable for 18 months. Formulation $\mathrm{F}_{7}$ gave a linear release pattern up to $12 \mathrm{~h}$. The release of ciprofloxacin from formulation $\mathrm{F}_{7}$ followed zero-order kinetics. The release mechanism was found to be diffusion-controlled as the Higuchi equation was obeyed.

Conclusions. Ciprofloxacin hydrochloride-containing matrix tablets were prepared successfully. The tablets had good integrity and were found stable for 18 months.

Key words: ciprofloxacin hydrochloride, diffusion-controlled, Ethoce ${ }^{T^{T M}} 100$ Premium, Eudragit ${ }^{\oplus}$ RS PO, matrix tablet

DOI

$10.17219 / \mathrm{pim} / 90020$

Copyright

○ 2017 by Wroclaw Medical University

This is an article distributed under the terms of the Creative Commons Attribution Non-Commercial License (http://creativecommons.org/licenses/by-nc-nd/4.0/) 


\section{Introduction}

The rationale of designing an oral controlled release drug delivery system is to achieve a predetermined and reproducible drug release profile from the system. ${ }^{1}$ Antibacterials are currently largely available on the market in the form of conventional dosage forms. Due to limitations in the use of conventional dosage forms, alternative dosage forms, such as sustained-release products, have been developed. Such products are available on the market only for a few drugs of these categories. Many antibacterials are still used in conventional dosage forms. There is a need to develop controlled-release drug delivery systems for these categories, so as to optimize the therapy and accrue the numerous benefits of controlled-release drug delivery systems. Antibiotics are substances produced by various species of microorganisms that suppress the growth of other microorganisms. ${ }^{2}$ Common usage often extends the term "antibiotics" to include synthetic antimicrobial agents, such as sulfonamides and quinolones. The recent introduction of fluorinated 4-quinolones, such as ciprofloxacin and ofloxacin, represents an important therapeutic advance, since these agents have a broad antimicrobial activity and are effective after oral administration for the treatment of a wide variety of infectious diseases. ${ }^{3}$ Peak serum levels are obtained within $1-3 \mathrm{~h}$ after administering an oral dose of $200 \mathrm{mg}$, with peak levels ranging from $0.7 \mu \mathrm{g} / \mathrm{mL}$ (sparfloxacin) to $2.9 \mu \mathrm{g} / \mathrm{mL}$ (trovafloxacin). ${ }^{4}$ Fluoroquinolones are potent bactericidal agents against Escherichia coli and various species of Salmonella, Shigella, Enterobacter, Campylobacter, and Niesseria. ${ }^{5}$

Ciprofloxacin is a broad-spectrum fluoroquinolone antibacterial drug to which most Gram-negative bacteria and many Gram-positive bacteria are highly susceptible. ${ }^{6}$ It has proven effective in the treatment of many types of systemic infections as well as acute and chronic infections of the urinary tract. ${ }^{7}$ It is generally well tolerated; however, ciprofloxacin may produce nausea, vomiting, diarrhea, and abdominal discomfort after administration. ${ }^{8}$ The gastric irritation and dose dumping problem of ciprofloxacin can be avoided by formulating a controlled-release drug delivery system. The oral dose of ciprofloxacin in adults is $500-750 \mathrm{mg}$ for $12 \mathrm{~h}$. The bioavailability of ciprofloxacin is $60-80 \%$. The serum half-life for ciprofloxacin is $3.3 \mathrm{~h}$. Fluoroquinolones are administered repeatedly, twice a day for 5 days, during the course of therapy. Hence, they require repeated administration. ${ }^{9,10}$ Thus, ciprofloxacin qualifies as a candidate for a controlled-release drug delivery system.

To overcome the limitations of immediate release formulations of ciprofloxacin hydrochloride, the purpose of the present study was to design and develop matrix systems using Ethocel ${ }^{\mathrm{TM}}$ and Eudragit ${ }^{\circledR}$ RS PO as a solubility retardant to maintain a sustained release profile.

\section{Material and methods}

\section{Material}

Ciprofloxacin hydrochloride was received as a gift sample from Nicholas Piramal Ltd., Indore, India. Ethocel ${ }^{\mathrm{TM}}$ 100 Premium and Eudragit ${ }^{\circledR}$ RS PO were received as a gift sample from Evonik Laboratory, Mumbai, India. Granular dicalcium phosphate (DCP) was received as a gift sample from Dhara Life Science Pvt. Ltd., Ahmedabad, India. Microcrystalline cellulose (Avicel PH 112) was received as a gift sample from NB Entrepreneurs, Nagpur, India. Croscarmellose sodium (Ac-Di-Sol) was received as a gift sample from Signet Chemical Corporation, Mumbai, India. Isopropyl alcohol and dichloromethane were purchased from Thomas Baker (Chemicals) Pvt. Ltd., Mumbai, India. Sodium starch glycolate, microcrystalline cellulose, sodium lauryl sulfate, magnesium stearate, and purified talc were purchased from Nice Chemicals Ltd., Cochin, India.

\section{Methods}

Preparation of ciprofloxacin hydrochloride matrix tablets

Ciprofloxacin hydrochloride and a 75\% amount of Ethocel 100 Premium and Eudragit RS PO were passed through \#40 sieve and mixed thoroughly (Table 1). The remaining amount of the polymers was dissolved in $30 \mathrm{~mL}$ of an isopropyl alcohol and dichloromethane (1:1) mixture. The resultant solution was used as a binding agent to prepare a wet mass. The wet mass was passed through \#12 sieve to form granules. The wet granules were dried in a hot air oven at $45 \pm 5^{\circ} \mathrm{C}$ for $1 \mathrm{~h}$. The dried granules were passed through \#20 sieve and mixed with the remaining ingredients previously passed through \#40 sieve. The granules were lubricated and compressed using a $19.5 \times 10 \mathrm{~mm}$ size punch (capsule shape) in a rotary tablet press (Rimek Mini Press 1; Karnavati Engineering Ltd., Ahmedabad, India).

\section{Preparation of conventional ciprofloxacin hydrochloride tablets}

The composition of the conventional tablets of ciprofloxacin is shown in Table 2. Ciprofloxacin hydrochloride, Avicel PH 112, sodium lauryl sulfate and Primojel ${ }^{\circledR}$ were passed through \#40 sieve. Starch paste $(10 \% \mathrm{w} / \mathrm{w})$ was used as a binding agent. The wet mass was passed through \#12 sieve and dried for $1 \mathrm{~h}$. The dried granules were passed through \#20 sieve. Lubricant and the other excipients were passed through \#40 sieve and mixed with the dried granules for $5 \mathrm{~min}$. The granules were compressed using a $16.4 \times 8 \mathrm{~mm}$ size punch (capsule shape) in a rotary tablet press (Rimek Mini Press 1; Karnavati Engineering Ltd., Ahmedabad, India). 
Table 1. Composition of the matrix tablets of ciprofloxacin hydrochloride (formulations $F_{1}-F_{9}$ )

\begin{tabular}{|c|c|c|c|c|c|c|c|c|c|}
\hline \multirow{2}{*}{ Ingredients } & \multicolumn{9}{|c|}{ Quantity [mg/tablet] } \\
\hline & $\mathrm{F}_{1}$ & $\mathrm{~F}_{2}$ & $\mathrm{~F}_{3}$ & $\mathrm{~F}_{4}$ & $\mathrm{~F}_{5}$ & $\mathrm{~F}_{6}$ & $\mathrm{~F}_{7}$ & $\mathrm{~F}_{8}$ & $\mathrm{~F}_{9}$ \\
\hline Ciprofloxacin hydrochloride & 580 & 580 & 580 & 580 & 580 & 580 & 580 & 580 & 580 \\
\hline Ethocel $^{T M} 100$ Premium & 100 & 150 & 200 & - & 300 & 300 & 300 & - & - \\
\hline Eudragit ${ }^{\circledR}$ RS PO & 200 & 150 & 100 & 300 & - & - & - & 300 & 300 \\
\hline Granular DCP & 60 & 50 & 40 & 40 & 40 & 50 & 60 & 50 & 60 \\
\hline Avicel PH 112 & 40 & 50 & 60 & 60 & 60 & 50 & 40 & 50 & 40 \\
\hline Magnesium stearate & 10 & 10 & 10 & 10 & 10 & 10 & 10 & 10 & 10 \\
\hline Purified talc & 10 & 10 & 10 & 10 & 10 & 10 & 10 & 10 & 10 \\
\hline
\end{tabular}

DCP - dioctyl phthalate.

Table 2. Composition of a conventional tablet of ciprofloxacin hydrochloride (formulation $\mathrm{F}_{10}$ )

\begin{tabular}{|l|c|}
\hline \multicolumn{1}{|c|}{ Ingredients } & Quantity [mg/tablet] \\
\hline Ciprofloxacin hydrochloride & 580 \\
Microcrystalline cellulose & 140 \\
Sodium lauryl sulphate & 10 \\
Sodium starch glycolate (Primojel ${ }^{\circledR}$ ) & 27 \\
Starch (for paste in water) & 60 \\
Ac-Di-Sol & 15 \\
Magnesium stearate & 6 \\
Purified talc & 6 \\
Purified water & q.S. \\
\hline
\end{tabular}

q.s. - quantum satis (enough).

\section{Evaluation of tablets}

The tablets produced were characterized for weight variation, hardness using a Monsanto hardness Tester (PI-924, Slit Lamp KFCO International, Ambala, India), friability using a friabilator meeting United States Pharmacopeia (USP) requirements (EF-2; Electrolab, Mumbai, India), and thickness using a Digital Vernier Caliper (500-197-20, Mitutoyo, Japan). ${ }^{11,12}$ Each measurement was done in triplicate.

The release study of ciprofloxacin hydrochloride from the prepared tablets was carried out using USP dissolution apparatus II. The dissolution study was carried out in $900 \mathrm{~mL}$ of $0.1 \mathrm{~N} \mathrm{HCl}(\mathrm{pH} \mathrm{1.2)}$ ) for the initial $2 \mathrm{~h}$ and $900 \mathrm{~mL}$ phosphate buffer solution (PBS; pH 7.4) for the next $10 \mathrm{~h}$ at $100 \mathrm{rpm}$. The temperature was maintained at $37 \pm 0.5^{\circ} \mathrm{C}$. Aliquots $(5 \mathrm{~mL})$ were withdrawn at every $1 \mathrm{~h}$ interval till the $12^{\text {th }} \mathrm{h}$. The sink condition was maintained by replacing an equivalent amount of dissolution medium after each sampling. The samples were analyzed using a ultraviolet (UV) spectrophotometer (UV 3000+; LabIndia Instruments, Mumbai, India) at $278 \mathrm{~nm}$. The sampling was done in triplicate from each batch. ${ }^{13}$

To study the drug release behavior and kinetics, the dissolution data was fitted in various kinetic models viz. zeroorder (cumulative amount of drug released against time) and first-order kinetics (log cumulative percentage of drug remaining against time). The drug release mechanism was investigated using Higuchi's model (cumulative percentage of drug released against the square root of time). ${ }^{14}$

\section{Stability study}

Stability studies on matrix tablets (formulations $\mathrm{F}_{4}, \mathrm{~F}_{5}$ and $F_{7}$ ) were carried out according to the International Council for Harmonisation of Technical Requirements for Pharmaceuticals for Human Use (ICH) guidelines. Three tablets of each formulation were withdrawn, and observed visually for physical appearance (color or texture), drug content and dissolution profile at $0,30^{\text {th }}, 60^{\text {th }}, 90^{\text {th }}$ and $180^{\text {th }}$ day. From the data, shelf life $\left(t_{90 \%}\right)$ was calculated. ${ }^{15}$

\section{Results and discussion}

Ciprofloxacin hydrochloride is water-soluble and it is rapidly and well absorbed from the gastrointestinal tract. The oral bioavailability of ciprofloxacin hydrochloride is $70 \%$. Peak plasma concentration is obtained within $1-2 \mathrm{~h}$ and the plasma half-life of ciprofloxacin is $3-5 \mathrm{~h}$. This results in rapid absorption and elimination of ciprofloxacin hydrochloride from a conventional tablet. In order to control the release of the drug, rate-retarding polymers, such as ethyl cellulose (Ethocel ${ }^{\mathrm{TM}} 100$ Premium) and/or Eudragit ${ }^{\circledR}$ RS PO, were used in different proportions. Nine formulations $\left(\mathrm{F}_{1}-\mathrm{F}_{9}\right)$ were prepared as matrix tablets with individual polymers and mixtures of the 2 polymers. For comparison, 1 formulation $\left(\mathrm{F}_{10}\right)$ was prepared by wet granulation method, using starch paste as a binding agent.

A spectrophotometric analytical method for ciprofloxacin was developed using distilled water as a solvent. The analytical wavelength of $278 \mathrm{~nm}$ was identified. The E1\% solution gave 974. The molar extinction coefficient was $2.5 \times 10^{5}$. Beer-Lambert law was obeyed in the concentration range $1-10 \mu \mathrm{g} / \mathrm{mL}$. The $\mathrm{R} 2$ value $(0.9998)$ proved the validity of the analytical method used.

The granules were evaluated for percent moisture content. The moisture content was within acceptable limits. The tablets (formulations $F_{1}-F_{10}$ ) were evaluated for 
physical integrity such as thickness, hardness, compressional weight, friability, and drug content. The results are presented in Table 3. The tablet surface was free of cracks and slumps. Weight variation is the major test to be checked frequently. Variation in the weight of the tablet leads to either undermedication or overdose. The average weight of the matrix tablets (formulations $F_{1}-F_{9}$ ) ranged from 980 to $1012 \mathrm{mg}$ (expected weight of each tablet was $1000 \mathrm{mg}$ ). The weight of all tablets was within $\pm 5 \%$ range of average weight. The average weight of the conventional tablet (formulation $\mathrm{F}_{10}$ ) was $855 \pm 5 \mathrm{mg}$ (expected weight was $844 \mathrm{mg}$ ).

Friability decreased as the binder concentration increased. An increase in binder concentration will enhance the formation of stronger inter-particulate bonds between the granules during compression. This means that the tablets would offer greater resistance to shock and abrasion since there is a stronger adhesive bonding of the granules at high binder concentrations. In general, tablets had good friability profiles $(<0.8 \%)$.

The hardness of a tablet is an indication of its strength. The tablet should be stable to mechanical stress during handling and transportation. An increase in binder concentration increased the hardness of the tablets. Hardness of the tablets (formulations $F_{1}-F_{10}$ ) varied from 6.0 to $7.5 \mathrm{~kg} / \mathrm{cm}^{2}$. The hardness was satisfactory $\left(5-10 \mathrm{~kg} / \mathrm{cm}^{2}\right)$ (Table 3$)$.

Tablets should have uniform thickness and these values are used to adjust the initial stage of compression. The thickness of the tablets (formulations $F_{1}-F_{9}$ ) varied from 6.2 to $6.5 \mathrm{~mm}$, which is permissible as per the standards (usually a range of $\pm 5 \%$ around the average thickness is allowed). The thickness of the conventional tablets (formulation $\mathrm{F}_{10}$ ) ranged between 7.8 and $8.0 \mathrm{~mm}$ (Table 3 ). The thickness of all the formulations was found to be uniform.

The results showed that the disintegration time of the tablets increased from $5 \pm 0.17$ to $11 \pm 0.52 \mathrm{~min}$ as the binder concentration increased from 0.25 to $1.0 \%$ (Table 3 ). The drug content was found to be in the range of $93.0-98.08 \%$. The percentage moisture

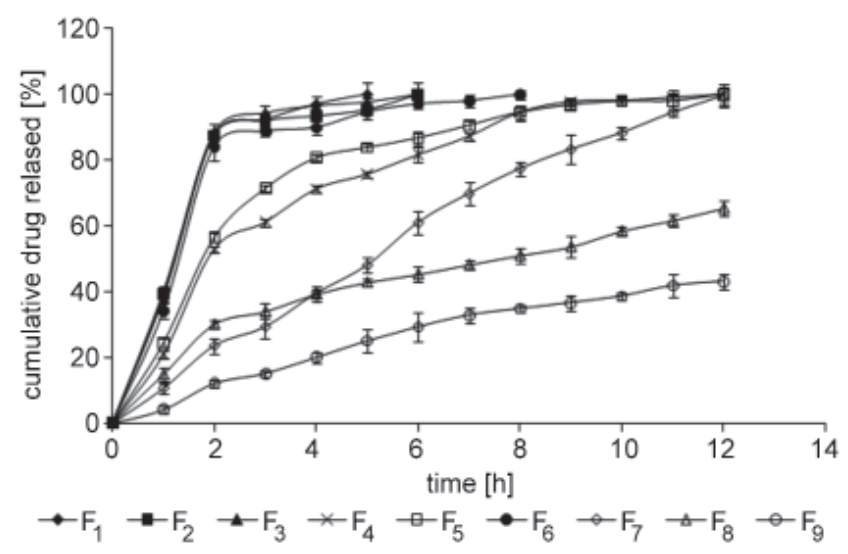

Fig. 1. In vitro release profile of ciprofloxacin hydrochloride from matrix tablets (formulations $F_{1}-F_{9}$ ) in $0.1 \mathrm{~N} \mathrm{HCl}(\mathrm{pH} 1.2$ ) for initial $2 \mathrm{~h}$ and phosphate buffer solution (PBS) $(\mathrm{pH} 7.4)$ for the next $10 \mathrm{~h}$ at $37 \pm 0.2^{\circ} \mathrm{C}($ mean $\pm \mathrm{SD}, \mathrm{n}=3)$

content of the granules at the time of compression (6.1-8.3\%) was satisfactory for compression of the ciprofloxacin tablets. Drug content ranged from $96.4 \%$ to $96.6 \%$ of the expected drug content, which satisfies the compendial requirements. Thus, ciprofloxacin tablets with good physical integrity were obtained.

The in vitro release data of the 9 formulations (formulations $F_{1}-F_{9}$ ) are recorded in Fig. 1. Formulation $F_{10}$ released $97.7 \%$ of the drug within $30 \mathrm{~min}$ of the dissolution study and was unsuitable for controlled release. The results of the in vitro release study indicated that the release of ciprofloxacin from 5 formulations (formulations $\mathrm{F}_{1}, \mathrm{~F}_{2}, \mathrm{~F}_{3}, \mathrm{~F}_{6}$, and $\mathrm{F}_{10}$ ) was very fast (>80\% in $2 \mathrm{~h}$ ). Hence, these formulations were not suitable for controlled release of ciprofloxacin. Formulations $\mathrm{F}_{4}, \mathrm{~F}_{5}, \mathrm{~F}_{7}, \mathrm{~F}_{8}$, and $\mathrm{F}_{9}$ gave a linear release pattern of ciprofloxacin up to $12 \mathrm{~h}$. The release rate was slow and incomplete from formulation $\mathrm{F}_{8}(63.35 \%)$ and $\mathrm{F}_{9}(43.05 \%)$ after $12 \mathrm{~h}$ of dissolution study. Hence, formulations $\mathrm{F}_{8}$ and $\mathrm{F}_{9}$ were considered unsuitable for controlled release. Formulations $\mathrm{F}_{4}, \mathrm{~F}_{5}$ and $\mathrm{F}_{7}$ showed a continuous and complete release of ciprofloxacin up to $12 \mathrm{~h}$ (Fig. 1). A comparison of regres-

Table 3. Physical and chemical parameters of the matrix tablets of ciprofloxacin*

\begin{tabular}{|c|c|c|c|c|c|c|c|c|c|c|}
\hline \multirow{2}{*}{ Parameter $\downarrow$} & \multicolumn{10}{|c|}{ Formulations } \\
\hline & $\mathrm{F}_{1}$ & $F_{2}$ & $\mathrm{~F}_{3}$ & $\mathrm{~F}_{4}$ & $\mathrm{~F}_{5}$ & $\mathrm{~F}_{6}$ & $\mathrm{~F}_{7}$ & $\mathrm{~F}_{8}$ & $\mathrm{~F}_{9}$ & $\mathrm{~F}_{10}$ \\
\hline $\begin{array}{l}\text { Moisture content } \\
{[\% \mathrm{w} / \mathrm{w}]}\end{array}$ & $\begin{array}{c}7.40 \\
\pm 1.03\end{array}$ & $\begin{array}{r}7.30 \\
\pm 0.57\end{array}$ & $\begin{array}{r}6.90 \\
\pm 0.65\end{array}$ & $\begin{array}{c}7.30 \\
\pm 0.97\end{array}$ & $\begin{array}{c}6.87 \\
\pm 1.51\end{array}$ & $\begin{array}{c}5.93 \\
\pm 0.85\end{array}$ & $\begin{array}{c}6.50 \\
\pm 1.06\end{array}$ & $\begin{array}{c}6.00 \\
\pm 0.96\end{array}$ & $\begin{array}{c}5.69 \\
\pm 1.13\end{array}$ & $\begin{array}{c}6.10 \\
\pm 0.82\end{array}$ \\
\hline $\begin{array}{l}\text { Thickness } \\
{[\mathrm{mm}]}\end{array}$ & $\begin{array}{c}6.40 \\
\pm 0.52\end{array}$ & $\begin{array}{c}6.25 \\
\pm 1.24\end{array}$ & $\begin{array}{c}6.50 \\
\pm 1.61\end{array}$ & $\begin{array}{c}6.12 \\
\pm 1.30\end{array}$ & $\begin{array}{c}6.30 \\
\pm 0.87\end{array}$ & $\begin{array}{c}6.40 \\
\pm 1.25\end{array}$ & $\begin{array}{c}6.40 \\
\pm 1.25\end{array}$ & $\begin{array}{c}6.20 \\
\pm 0.82\end{array}$ & $\begin{array}{c}6.40 \\
\pm 1.73\end{array}$ & $\begin{array}{c}7.90 \\
\pm 1.53\end{array}$ \\
\hline $\begin{array}{l}\text { Hardness } \\
{\left[\mathrm{kg} / \mathrm{cm}^{2}\right]}\end{array}$ & $\begin{array}{r}6.5 \\
\pm 1.57\end{array}$ & $\begin{aligned} & 7.0 \\
\pm & 2.51\end{aligned}$ & $\begin{array}{r}6.5 \\
\pm 1.52\end{array}$ & $\begin{array}{c}6.0 \\
\pm 0.84\end{array}$ & $\begin{array}{c}6.5 \\
\pm 0.72\end{array}$ & $\begin{aligned} & 7.0 \\
\pm & 1.18\end{aligned}$ & $\begin{array}{c}7.1 \\
\pm 1.92\end{array}$ & $\begin{aligned} & 7.5 \\
\pm & 1.23\end{aligned}$ & $\begin{array}{c}6.7 \\
\pm 0.85\end{array}$ & $\begin{array}{c}6.5 \\
\pm 0.79\end{array}$ \\
\hline $\begin{array}{l}\text { Compressional } \\
\text { wt [mg] (practical) }\end{array}$ & $\begin{array}{r}990 \\
\pm 5.39\end{array}$ & $\begin{array}{c}987 \\
\pm 7.64\end{array}$ & $\begin{array}{r}992 \\
\pm 5.95\end{array}$ & $\begin{array}{c}980 \\
\pm 6.91\end{array}$ & $\begin{array}{c}997 \\
\pm 5.86\end{array}$ & $\begin{array}{c}984 \\
\pm 9.57\end{array}$ & $\begin{array}{c}1002 \\
\pm 13.27\end{array}$ & $\begin{array}{c}1008 \\
\pm 11.82\end{array}$ & $\begin{array}{r}1012 \\
\pm 9.82\end{array}$ & $\begin{aligned} & 852 \\
\pm & 10.28\end{aligned}$ \\
\hline $\begin{array}{l}\text { Friability } \\
{[\%]}\end{array}$ & $\begin{array}{c}0.32 \\
\pm 0.002\end{array}$ & $\begin{array}{c}0.14 \\
\pm 0.001\end{array}$ & $\begin{array}{c}0.47 \\
\pm 0.01\end{array}$ & $\begin{array}{c}0.38 \\
\pm 0.95\end{array}$ & $\begin{array}{c}0.48 \\
\pm 0.11\end{array}$ & $\begin{array}{c}0.56 \\
\pm 0.06\end{array}$ & $\begin{array}{c}0.68 \\
\pm 0.15\end{array}$ & $\begin{array}{c}0.71 \\
\pm 0.08\end{array}$ & $\begin{array}{c}0.73 \\
\pm 0.14\end{array}$ & $\begin{array}{c}0.65 \\
\pm 0.07\end{array}$ \\
\hline $\begin{array}{l}\text { Drug content } \\
{[\%]}\end{array}$ & $\begin{array}{l}98.20 \\
\pm 4.67\end{array}$ & $\begin{array}{r}96.50 \\
\pm 7.61\end{array}$ & $\begin{array}{l}98.90 \\
\pm 5.62\end{array}$ & $\begin{array}{l}98.70 \\
\pm 3.52\end{array}$ & $\begin{array}{l}98.50 \\
\pm 2.64\end{array}$ & $\begin{array}{l}99.60 \\
\pm 4.18\end{array}$ & $\begin{array}{l}98.70 \\
\pm 4.09\end{array}$ & $\begin{array}{l}97.35 \\
\pm 5.84\end{array}$ & $\begin{array}{l}96.05 \\
\pm 3.61\end{array}$ & $\begin{array}{r}97.08 \\
\pm 5.57\end{array}$ \\
\hline
\end{tabular}

* The average of 10 determinations were given and the values are rounded off to a significant decimal. 
sion equations of zero-order for formulations $\mathrm{F}_{4}, \mathrm{~F}_{5}$ and $\mathrm{F}_{7}$ (Fig. 2) revealed that the slope and regression coefficient $\left(R^{2}\right)$ values for formulation $F_{7}$ were higher when compared to formulations $\mathrm{F}_{4}$ and $\mathrm{F}_{5}$ and the intercept value (constant) was less for formulation $F_{7}$ than for formulations $F_{4}$ and $F_{5}$. The $x$ coefficient value was higher for formulation $F_{7}$. Based on these results, formulation $\mathrm{F}_{7}$ was selected as the best. The regression graphs and equations of the zero-order release for $F_{4}, F_{5}$ and $F_{7}$ are shown in Fig. 2. These results indicate that formulation $\mathrm{F}_{7}$ of the ciprofloxacin matrix tablets gave consistent release of ciprofloxacin up to $12 \mathrm{~h}$.

The in vitro release of ciprofloxacin from the selected formulation $\left(\mathrm{F}_{7}\right)$ was analyzed for determination of the release kinetics. The data was processed into graphs to elucidate the linear relationship, i.e., kinetic principles. The regression analysis was done using Microsoft Excel statistical functions (Microsoft, Redmond, USA). The equations are given below:

Zero-order:

$$
y=8.1937 t+7.1653 ; \quad \mathrm{n}=12 ; \quad \mathrm{R}^{2}=0.9847
$$

First-order:

$$
y=0.0760 \log t+1.215 ; \quad \mathrm{n}=12 ; \quad \mathrm{R}^{2}=0.8606
$$

As per the above equations, the release of ciprofloxacin hydrochloride followed zero-order kinetics, as the $\mathrm{R}^{2}$ value was higher for zero-order than for first-order.

The release of ciprofloxacin from the matrix tablets was expected to be diffusion-rate-controlled. Hence, the data was processed as per the Higuchi equation. The regression equation for the data is given below:

Higuchi equation:

$$
y=37.936 t^{1 / 2}+32.043 ; \quad \mathrm{n}=12 ; \quad \mathrm{R}^{2}=0.9901
$$

The high $\mathrm{R}^{2}$ value indicates that the release mechanism of ciprofloxacin from the matrix tablets was diffusioncontrolled.

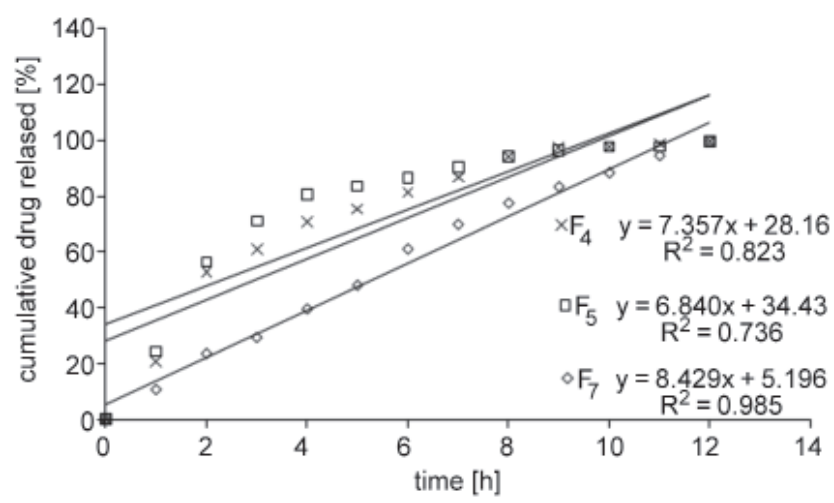

Fig. 2. Regression analysis of in vitro release data for the selected matrix tablets of ciprofloxacin hydrochloride (formulations $F_{4}, F_{5}$ and $F_{7}$ )

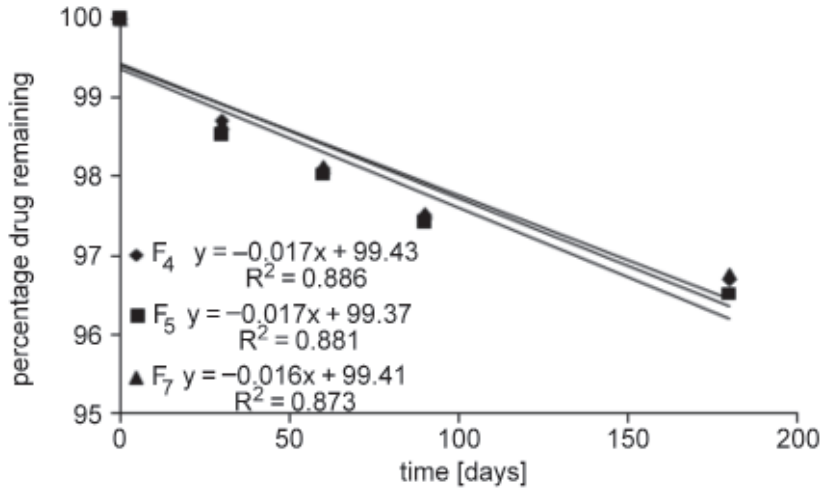

Fig. 3. Degradation profiles of ciprofloxacin hydrochloride tablets (formulations $\mathrm{F}_{4}, \mathrm{~F}_{5}$ and $\mathrm{F}_{7}$ )

Stability studies on the matrix tablets (formulations $\mathrm{F}_{4}$, $\mathrm{F}_{5}$ and $\mathrm{F}_{7}$ ) were carried out according to the $\mathrm{ICH}$ guidelines. Three tablets of each formulation were withdrawn, observed visually for physical appearance and analyzed for drug content at $0,30^{\text {th }}, 60^{\text {th }}, 90^{\text {th }}$, and $180^{\text {th }}$ day. All tablets retained physical integrity and no visual differences in color or texture were observed. The average drug content of the matrix tablets remaining at different intervals of time for each of the 3 formulations is shown in Table 4. From the data, shelf life (t90\%) was calculated. The stability data from Table 4 (time vs \% of drug remaining) for formulations $F_{4}, F_{5}$ and $F_{7}$ was processed into graphs using Microsoft Excel (Miscosoft, Redmond, USA) and regression equations were calculated for each formulation (Fig. 3). Degradation of ciprofloxacin followed first-order kinetics, as the regression coefficient value of the firstorder plot was higher.

From the first-order plots, $k$ values were calculated and substituted in the shelf life equation. The calculated values are given in Table 5. Percent drug content at 0 time and after 180 days was taken as $C_{0}$ and $C$ (Table 5).

Table 4. Results of stability study of ciprofloxacin matrix tablets (formulations $\mathrm{F}_{4}, \mathrm{~F}_{5}$ and $\mathrm{F}_{7}$ )

\begin{tabular}{c|c|c|c|c|c|c|}
\multirow{2}{*}{\begin{tabular}{c}
\multirow{2}{*}{$\begin{array}{c}\text { Time } \\
\text { [days] }\end{array}$} \\
\cline { 2 - 8 }
\end{tabular}} & \multicolumn{2}{|c|}{$\mathrm{F}_{4}$} & \multicolumn{2}{c|}{$\mathrm{F}_{5}$} & \multicolumn{2}{c|}{$\mathrm{F}_{7}$} \\
\cline { 2 - 8 } & {$[\mathrm{mg}]$} & $\%$ & {$[\mathrm{mg}]$} & $\%$ & {$[\mathrm{mg}]$} & $\%$ \\
\hline 0 & 580 & 100 & 580 & 100 & 580 & 100 \\
30 & 572.6 & 98.72 & 571.5 & 98.53 & 572.3 & 98.68 \\
60 & 569.0 & 98.11 & 568.7 & 98.05 & 569.1 & 98.12 \\
90 & 565.6 & 97.52 & 565.1 & 97.43 & 565.8 & 97.55 \\
180 & 560.9 & 96.7 & 559.9 & 96.53 & 561.3 & 96.78 \\
\hline
\end{tabular}

Table 5. Shelf life (t90\%) of matrix tablet formulations of ciprofloxacin hydrochloride (formulations $F_{4}, F_{5}$ and $F_{7}$ )

\begin{tabular}{|c|c|c|}
\hline Formulation & $K \times 10^{-4}$ & $t_{90 \%}[$ days $]$ \\
\hline F4 & 1.861 & 565 \\
F5 & 1.960 & 547 \\
F7 & 1.821 & 555 \\
\hline
\end{tabular}


The results of the stability study of the 3 formulations of ciprofloxacin matrix tablets revealed that these formulations are stable for a minimum period of 1.5 years. Analysis of the results gave significant observations, which were discussed in the light of current concepts and interrelationships among the other experimental results.

\section{Conclusions}

Ciprofloxacin hydrochloride-containing matrix tablets were prepared successfully. The tablets had good integrity and were stable for 18 months. Formulation $\mathrm{F}_{7}$ gave a linear release pattern up to $12 \mathrm{~h}$. The release of ciprofloxacin from formulation $\mathrm{F}_{7}$ followed zero-order kinetics. The release mechanism was found to be diffusion-controlled as the Higuchi equation was obeyed.

\section{References}

1. Dash S, Murthy PN, Nath L, Chowdhury P. Kinetic modeling on drug release from controlled drug delivery systems. Acta Pol Pharm. 2010;67(3):217-223.

2. Raaijmakers JM, Vlami M, de Souza JT. Antibiotic production by bacterial biocontrol agents. Antonie van Leeuwenhoek. 2002;81(1-4):537-547.

3. Aminov R. History of antimicrobial drug discovery: Major classes and health impact. Biochem Pharmacol. 2017;133:4-19.

4. Stein GE. Pharmacokinetics and pharmacodynamics of newer fluoroquinolones. Clin Infect Dis. 1996;23:S19-S24.

5. Hassan Y, Alfadly SO, Azmin MN, et al. Bioequivalence evaluation of two different formulations of ciprofloxacin tablets in healthy volunteers. Singapore Med J. 2007;48(9):819-823.

6. Campoli-Richards DM, Monk JP, Price A, Benfield P, Todd PA, Ward A. Ciprofloxacin. A review of its antibacterial activity, pharmacokinetic properties and therapeutic use. Drugs. 1988;35(4):373-447.

7. Nicolle LE. Urinary tract infections in the elderly. Clin Geriatr Med. 2009;25:423-436.

8. Ball P. Ciprofloxacin: An overview of adverse experiences. J Antimicrob Chemother. 1986;18(Suppl D):187-193.

9. Segev S, Yaniv I, Haverstock D, Reinhart H. Safety of long-term therapy with ciprofloxacin: Data analysis of controlled clinical trials and review. Clin Infect Dis. 1999;28(2):299-308.

10. Bader MS, Hawboldt J, Brooks A. Management of complicated urinary tract infections in the era of antimicrobial resistance. Postgrad Med. 2010;122(6):7-15.

11. United State Pharmacopeia 24 / National Formulary 19. Asian Edition. Rockville, USA: USP Convention Inc; 2007.

12. Lachman L, Lieberman HA, Kanig JL. Theory and Practice of Industrial Pharmacy. $3^{\text {rd }}$ ed. Bombay, India: Varghese Publishing House; 1990:297-299.

13. Sharma G, Pawar VK, Garg G, Awasthi R, Kulkarni GT. Taste masking of promethazine hydrochloride using Eudragit E100 via solid dispersion technique to develop fast disintegrating tablets. Pharm Lett. 2010;2(3):83-94.

14. Awasthi R, Kulkarni GT, Ramana MV, et al. Dual crosslinked alginatepectin network as sustained release matrix for repaglinide. Int J Biol Macromol. 2017;97:721-732.

15. Ramana MV, Awasthi R, Ghisleni DDM, et al. Preparation and characterization of metoprolol tartrate containing matrix type transdermal drug delivery system. Drug Deliv Trans/ Res. 2017;7(1):66-76. 